\title{
Variation in the yield and essential oil of four chamomile varieties grown in Finland in 1985-1988
}

\author{
B. GALAMBOSI ${ }^{1}$, ZS. SZEBENI-GALAMBOSI ${ }^{1}$, M. REPCAK ${ }^{2}$ and P. CERNAJ ${ }^{2}$ \\ ${ }^{1}$ Agricultural Research Centre, South Savo Research Station, Karila, \\ SF-50600 Finland \\ ${ }^{2}$ Dept. of Special Biology, P.I. Safarik University of Kosice, Manesova 23, \\ 04167 Kosice, Czeshoslovakia
}

\begin{abstract}
Four chamomile (Matricaria recutita L.) varieties were grown at Puumala, Finland $\left(61^{\circ} 40^{\prime} \mathrm{N}, 28^{\circ} 15^{\prime} \mathrm{E}\right)$ in $1985-1989$ from spring sowings on stony till soil, pH 5.8. The weather conditions in the experimental years were very different. For instance between 1987 and 1988 there was a difference of $5,3^{\circ} \mathrm{C}$ in the mean temperature of the growing periods (MaySeptember). The four-year average of the fresh flower yield was $0.4(0.1-0.7) \mathrm{kg} / \mathrm{m}^{2}$. The yields varied greatly depending on the number of harvests, which depended on the weather conditions. One harvest could be obtained in 1986 and 1987, two in 1985 and three in 1988.

In spite of the different weather conditions there were no differences in the content and composition of the essential oil distilled from the dry flowers.
\end{abstract}

Index words: chamomile, varieties, flower yield, essential oil

\section{Introduction}

Chamomile (Matricaria recutita L.) is a native plant of the Finnish flora, but it occurs quite rarely due to the widespread use of herbicides in agriculture and on roadsides. All chamomile used in the pharmaceutical industry and sold in health shops a total of $8.7 \mathrm{t}$ to a value of FIM 521.000 was imported in 1982 (HÃLVÃ 1985).

Field experiments for production of chamomile were started in 1984 within the herb cultivation project of the University of Helsinki,
Finland, organised by the Department of Horticulture and the Pharmacognosy Division (Galambosi 1989). In addition to the agrotechnical experiment, observations on different cultivars and chemotypes have been started in order to study the effects of the climatic conditions on the herb yield and essential oil. So far there are no long time observations on chamomile cultivated in the Finnish climate. The very few experiments with chamomile in Finland are concerned with the accumulation of essential oil and the chamazulene content during ontogenesis (von SCHANTZ and SALO- 
NEN 1966), or with the effects of varions climatic factors on chamomile in comparative pot trials in Finland (Helsinki), central Europe (Münich), and Asia Minor (Ismir, Turkey) reported by Franz et al. (1986). The latest observations were carried out in 1984 during a one year experiment in which the morphological characters, yield and essential oil content and composition of seven chamomile species grown in parallel in Hungary and SouthFinland were studied (GALAmBosi et al. 1988).

The purpose of this work was to study the variation of flower yield and essential oil of four chamomile varieties during a longer period under normal field conditions in Finland.

\section{Material and methods}

The experiments were carried out at Puumala $\left(61^{\circ} 40^{\prime} \mathrm{N}, 28^{\circ} 15^{\prime} \mathrm{E}\right)$ in a stony till soil, $\mathrm{pH}$ 5.8. The agricultural methods were the same each year and similar to the general Hungarian methods (SvÁB 1978). The chamomile was sown in spring using $5 \mathrm{~kg} /$ ha seed $\left(5 \mathrm{~g} / 10 \mathrm{~m}^{2}\right)$ with diffuse surface sowing. The plot size was $10 \mathrm{~m}^{2}$ in two replications. The plots were fertilized with $50-80-85 \mathrm{~kg} / \mathrm{ha}$ nitrogen, phosphor and potassium at the time of soil preparation.

Harvesting was carried out with a handharvester, the flower and herb yields (stems with flowers) being separated by a $18 \mathrm{~mm}$ screen. During the four growing seasons one harvest was gathered in 1986 and 1987, two in 1985 and three in 1988. The flower and herb samples were dried at $30^{\circ} \mathrm{C}$ for $12 \mathrm{~h}$ and stored in paper bags at room temperature. The essential oil analyses were carried out in the laboratory of the Department of Special Biology, University of Kosice, Czeshoslovakia, in 1986-1988 from the first harvests, in 1988 from the second harvest as well. The essential oil was obtained by $2 \mathrm{~h}$ distillation of $2 \mathrm{~g}$ dry samples of the ground drug in three replications. The content of essential oil was determined gravimetrically (Hölz and DEMUTH 1975). The main components of the essential oil were determined by means of gas chromatography (REPCAK et al. 1980).

The chamomile varieties used in the experiment were Budakalaszi-2 (tetraploid, Hungary), Degumille (diploid, FRG), Csömöri (diploid, Hungary) and Bona (diploid, CSSR). Some morphological characters of the varieties, the sowing times and length of the growing periods, are presented in Tables $1-2$.

The data on the essential oil content and composition was studied by analyses of variance (SváB 1981).

The meteorological conditions during the experimental periods as measured by the Finnish Meteorological Institute, are presented in Figure 1. The climatic conditions were quite different in each year. In 1986 and 1988, the average temperature of the growing season was higher than 30 year average. In May-JuneJuly the average temperature was 2 to $4^{\circ} \mathrm{C}$ higher than the long term average. The effective temperature sum (calculated from the sum of the mean daily temperatures above $+5^{\circ} \mathrm{C}$ between May 15th and August 31th) was $1072^{\circ} \mathrm{C}$ in 1986 and $1168^{\circ} \mathrm{C}$ in 1988 .

In 1987 , on the other hand, the growing season was colder and rainier than the 30 year average, the temperature being 2 to $3^{\circ} \mathrm{C}$ lower and the precipitation $130 \mathrm{~mm}$ higher than the long-term average. The effective temperature sum was only $750^{\circ} \mathrm{C}$. The temperature in 1985 did not differ too much from the average, the effective temperature sum being $928^{\circ} \mathrm{C}$, but the second half of the growing period was very rainy. Thus the chamomile

Table 1. Length of the vegetation periods of chamomile during 1985-1988 at Puumala.

\begin{tabular}{lcccc}
\hline Year & $\begin{array}{c}\text { Sowing } \\
\text { date }\end{array}$ & \multicolumn{3}{c}{$\begin{array}{c}\text { Length of periods in days } \\
\text { from sowing to }\end{array}$} \\
\cline { 3 - 5 } & & $\begin{array}{c}\text { First } \\
\text { harvest }\end{array}$ & $\begin{array}{c}\text { Second } \\
\text { harvest }\end{array}$ & $\begin{array}{c}\text { Third } \\
\text { harvest }\end{array}$ \\
\hline 1985 & 17.5. & 77 & 98 & - \\
1986 & 15.5. & 64 & - & - \\
1987 & 28.5. & 84 & - & - \\
1988 & 16.5. & 59 & 78 & 115 \\
\hline & mean: & 71 & 88 & - \\
\hline
\end{tabular}



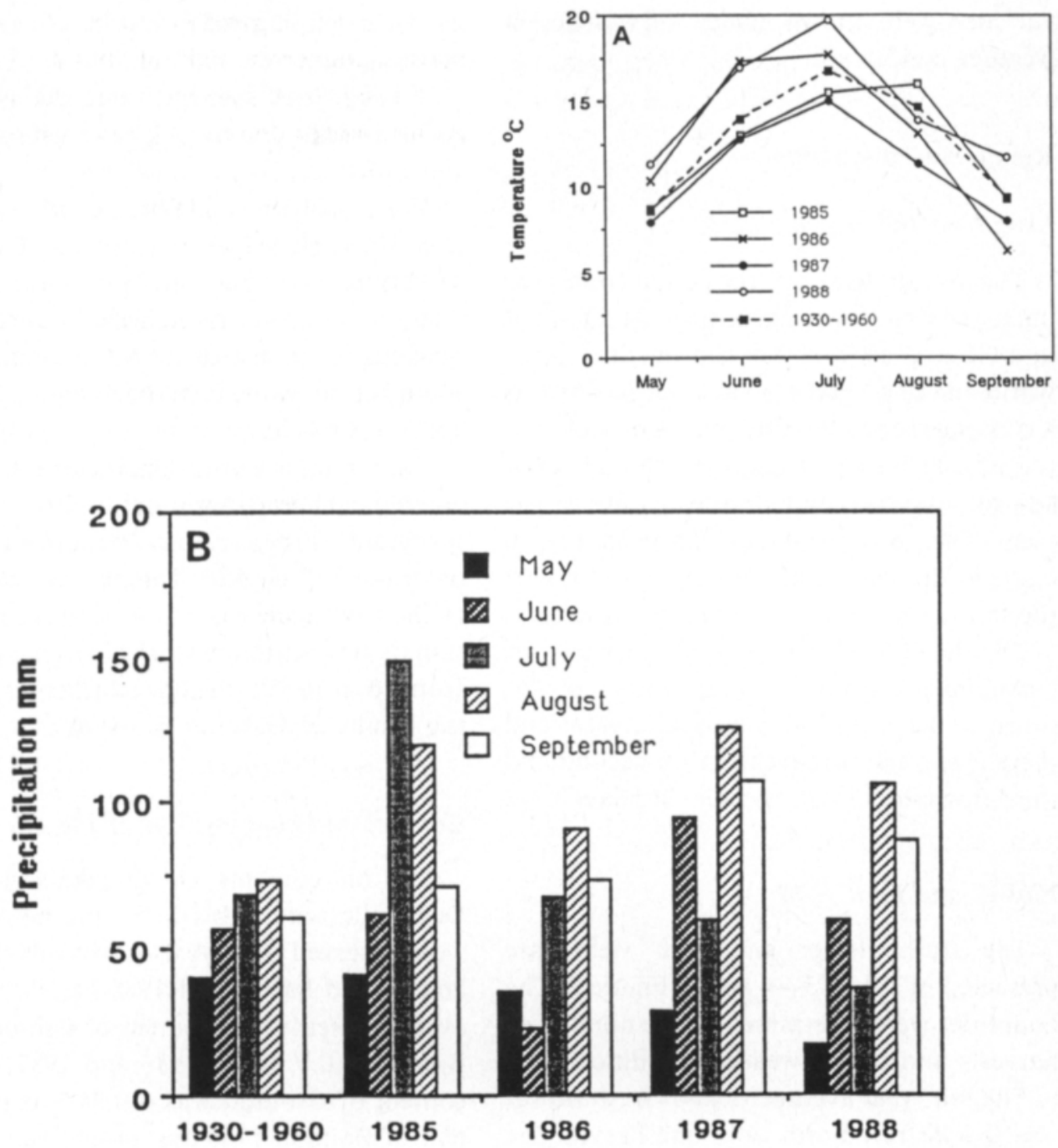

Fig. 1. Mean temperature (A) and precipitation (B) at Puumala during the experimental years and long-term averages (1930-1960).

Table 2. Height and morphological characters of flowers of chamomile varieties.

\begin{tabular}{|c|c|c|c|c|c|c|c|}
\hline \multirow[t]{2}{*}{ Variety } & \multicolumn{4}{|c|}{ Plant height at the first harvest time $(\mathrm{cm})$} & \multirow{2}{*}{$\begin{array}{l}\text { Torus diameter of } \\
\text { flower head }(\mathrm{cm}) \\
(1985)\end{array}$} & \multirow{2}{*}{\multicolumn{2}{|c|}{$\begin{array}{l}100 \text { flower mass }(\mathrm{g}) \\
\text { fresh dry } \\
\qquad(1985)\end{array}$}} \\
\hline & 1985 & 1986 & 1987 & Mean & & & \\
\hline Budakalaszi-2 & 72.6 & 54.8 & 63.7 & 63.7 & 0.955 & 28.1 & 5.27 \\
\hline Degumille & 60.8 & 47.6 & 49.5 & 52.6 & 0.825 & 15.0 & 2.81 \\
\hline Csömöri & 57.0 & 55.2 & 47.5 & 53.2 & 0.820 & 16.0 & 3.00 \\
\hline Bona & 52.8 & 54.9 & 46.2 & 51.3 & 0.865 & 15.1 & 2.81 \\
\hline
\end{tabular}

(figures are means of 20 plants, 50 flowerheads and fresh and dry mass of $10 \times 100$ flowerheads) 
varieties were grown under very different weather conditions.

\section{Results and discussion}

\section{Length of the growing periods}

The average length of the period from sowing to the first flower harvest was 71 days, but in 1986 and 1988 it was shorter due to the warm and dry weather (Table 1). In 1987, as a consequence of the cold and rainy summer, the first harvest was collected 84 days after sowing, and a second flowering did not appear. The spring sowings can generally be made in the middle of May after melting of the snow, when the soil surface is rather dry.

The length of the growing periods of chamomile depends on the weather conditions: if the spring sowing is successful and there is enough precipitation for second and third flowerings it can be $100-115$ days long.

\section{Flower and herb yield}

The fresh flower and herb yields are presented in Tables 3-4 and in Figure 2. The quantities were determined by the number of harvests and by the weather conditions.

The four year average yield of fresh flower was $0.4 \mathrm{~kg} / \mathrm{m}^{2}$. From only one harvest the yields were generally low $\left(0.17 \mathrm{~kg} / \mathrm{m}^{2}\right)$, especially in 1986 and 1987 . If second and third harvests were available, the yields reached $0.6-0.7 \mathrm{~kg} / \mathrm{m}^{2}$. The yields from spring sowings are at the same low level as reported by SvÁB (1978) and ZALECKI (1978). There was no connection between the flower or herb yield and the temperature sum of the growing season. The highest yields were achieved in 1985 and 1988 with low and high temperature sums ( 928 and $1168^{\circ} \mathrm{C}$, respectively), and the lowest yields were obtained in 1986 and 1987 , also with high and low values (1072 and $750^{\circ} \mathrm{C}$ ). The critical factor affecting the yield is the precipitation in early spring. If there is enough precipitation in the period of the vegetative growth of the roots and rosettes, the yield will be good as in 1985. In 1988, the warm summer caused continuous flowering and gave three harvests, but the yield remained lower due to lack of moisture in the soil in May.

The fresh herb yield obtained after separation of the flowers and which is suitable for distillation or extraction varied from 0.03 to $0.60 \mathrm{~kg} / \mathrm{m}^{2}$, being on average $0.20 \mathrm{~kg} / \mathrm{m}^{2}$. The quantitative herb yield of the second harvest was affected by the high precipitation in July, 1985. The response of the different varieties to the varying weather conditions was different. The highest flower and herb yields were produced by the varieties Degumille and $\mathrm{Bu}-$ dakalaszi-2. The yield of Bona was lowest due to the low flower mass. The average proportion of flowers in the total phytomass varied from 30 to $38 \%$, which is a little higher than the results of GASIC et al. (1989).

\section{Content and composition of the oil}

The oil contents of Budakalaszi-2 and Degumille were stable $1 \%$, and no changes were observed from year or between the first and second harvests in 1988 (Table 5). The average essential oil content of Csömöri and Bona was $0.9 \%$. In 1986 and 1987 , the oil content of Csömöri was $0.8 \%$, the oil content of Bona in 1986 and in the second harvest of 1988 was $0.7 \%$ and $0.8 \%$, respectively ( $\mathrm{p}<0.1)$.

The variation of the main components of the essential oil is shown in Table 5. There were clear differences between the varieties: Degumille, Csömöri and Bona seemed to be $\alpha$-bisabolol types (35-60\%), while Budakalaszi-2 is a bisabololoxide type cultivar. There were no big differences in the content of the main components caused by the very different weather conditions during the growing periods. The chamazulene content of the oils varied between 11 and $21 \%$. Some variation can be observed in the content of trans$\beta$-farnesene, the content being highest in the warmest year 1988 and especially in the second harvest. This observation is in accordance 


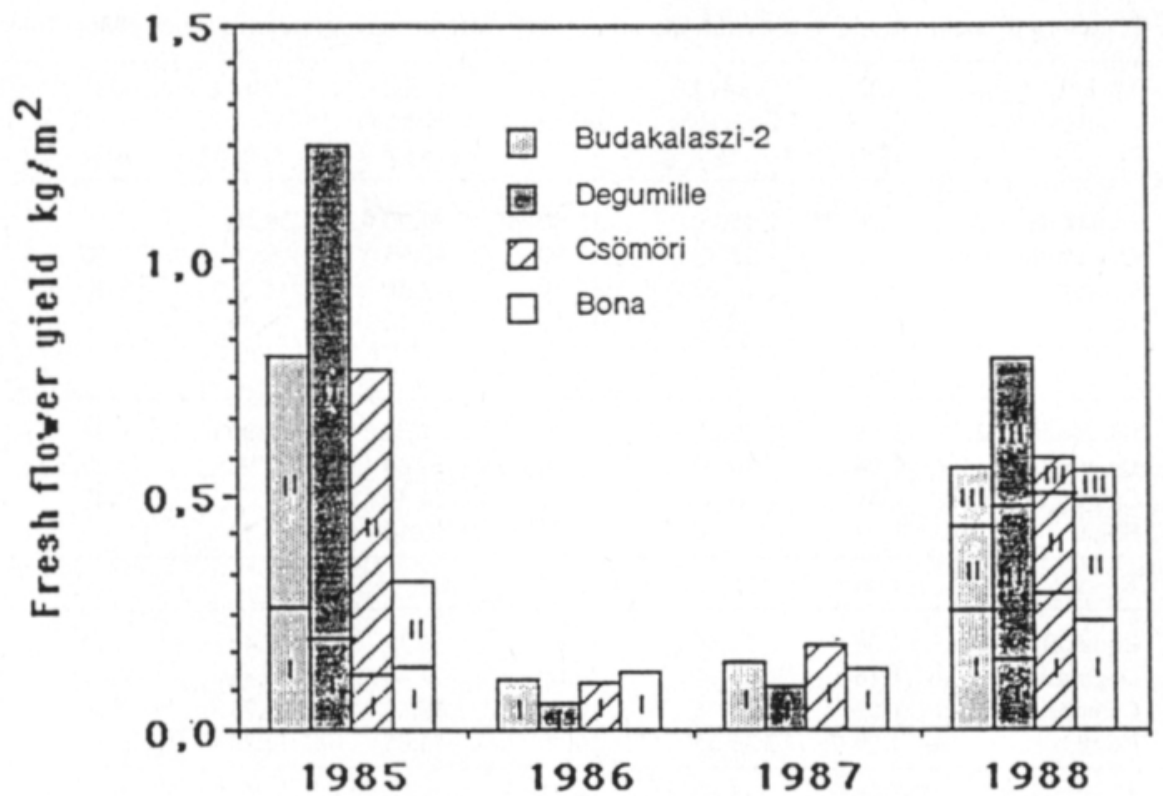

Fig. 2. Fresh flower yield of the chamomile varieties at Puumala 1985-1988. Roman numerals in the columns indicate first, second and third harvest.

with results of Gasic et al. (1989), who ied. Galambosi et al. (1988) stated the same reported the highest farnesene content of 16 tendency in a comparative study of 6 chamochamomile varieties in the warmest year stud- mile varieties grown in Hungary and Finland.

Table 3. Fresh flower yield $\left(\mathrm{g} / \mathrm{m}^{2}\right)$.

\begin{tabular}{|c|c|c|c|c|c|c|c|c|c|c|c|c|}
\hline \multirow[t]{2}{*}{ Variety } & \multicolumn{3}{|c|}{1985} & \multirow{2}{*}{$\frac{1986}{I}$} & \multirow{2}{*}{$\frac{1987}{I}$} & \multicolumn{4}{|c|}{1988} & \multicolumn{3}{|c|}{ Mean } \\
\hline & I & II & I + II & & & I & II & III & I + III & $\begin{array}{c}\text { All } \\
\text { together }\end{array}$ & $\begin{array}{c}\text { From I } \\
\text { harvests } \\
\text { only }\end{array}$ & $\begin{array}{c}\text { From } \\
\text { I-II-III } \\
\text { harvests }\end{array}$ \\
\hline Budakalaszi-2 & 341 & 453 & 794 & 107 & 146 & 314 & 149 & 96 & 558 & 401 & 227 & 676 \\
\hline Degumille & 200 & 1048 & 1248 & 100 & 91 & 154 & 329 & 306 & 789 & 557 & 136 & 1018 \\
\hline Csömöri & 112 & 640 & 752 & 103 & 183 & 332 & 192 & 57 & 581 & 404 & 182 & 666 \\
\hline Bona & 136 & 180 & 326 & 124 & 127 & 261 & 250 & 41 & 552 & 282 & 162 & 439 \\
\hline Mean & 197 & 580 & 780 & 108 & 137 & 265 & 230 & 125 & 620 & 411 & 177 & 699 \\
\hline
\end{tabular}

Table 4. Fresh herb yield after separation of the flowers $\left(\mathrm{g} / \mathrm{m}^{2}\right)$.

\begin{tabular}{|c|c|c|c|c|c|c|c|c|c|c|c|c|}
\hline \multirow[t]{2}{*}{ Variety } & \multicolumn{3}{|c|}{1985} & \multirow{2}{*}{$\frac{1986}{I}$} & 1987 & \multicolumn{4}{|c|}{1988} & \multicolumn{3}{|c|}{ Mean } \\
\hline & I & II & I + II & & I & I & II & III & I + III & $\begin{array}{c}\text { All } \\
\text { together }\end{array}$ & $\begin{array}{c}\text { From I } \\
\text { harvests } \\
\text { only }\end{array}$ & $\begin{array}{c}\text { From } \\
\text { I-II-III } \\
\text { harvests }\end{array}$ \\
\hline Budakalaszi-2 & 176 & 356 & 432 & 96 & 56 & 184 & 76 & 40 & 300 & 221 & 128 & 366 \\
\hline Degumille & 137 & 466 & 603 & 70 & 39 & 90 & 169 & 130 & 389 & 275 & 84 & 496 \\
\hline Csömöri & 92 & 259 & 351 & 110 & 97 & 194 & 98 & 24 & 316 & 218 & 123 & 333 \\
\hline Bona & 41 & 56 & 97 & 101 & 35 & 153 & 128 & 17 & 298 & 132 & 82 & 197,5 \\
\hline Mean & 111 & 284 & 370 & 95 & 56 & 155 & 118 & 53 & 326 & 211 & 104 & 348 \\
\hline
\end{tabular}


Table 5. Content and main compounds of the essential oil of different chamomile varieties 1986-1988.

\begin{tabular}{|c|c|c|c|c|c|c|c|c|}
\hline \multirow[t]{2}{*}{ Year } & \multirow[t]{2}{*}{ Variety } & \multirow{2}{*}{$\begin{array}{l}\text { Oil } \\
\%\end{array}$} & \multirow{2}{*}{$\begin{array}{c}\text { trans- } \beta- \\
\text { farnesene } \\
\%\end{array}$} & \multirow{2}{*}{$\begin{array}{c}\text { Chama- } \\
\text { zulene } \\
\%\end{array}$} & \multirow{2}{*}{$\begin{array}{c}-\alpha \text {-bisa- } \\
\text { bolol } \\
\%\end{array}$} & \multicolumn{2}{|c|}{ Bisabololoxide } & \multirow{2}{*}{$\begin{array}{c}\text { Bisabolo- } \\
\text { noxide } \\
\%\end{array}$} \\
\hline & & & & & & A $\%$ & B \% & \\
\hline \multirow[t]{5}{*}{1986} & Budakalaszi-2 & 1.06 & 17.40 & 15.73 & 3.33 & 39.00 & 5.13 & 3.66 \\
\hline & Degumille & 1.12 & 15.53 & 17.90 & 40.93 & 6.16 & 7.50 & + \\
\hline & Csömöri & 0.82 & 11.63 & 16.70 & 57.56 & 1.20 & 2.40 & + \\
\hline & Bona & 0.69 & 14.00 & 11.56 & 60.10 & 1.40 & 2.16 & + \\
\hline & $\mathrm{x}$ & 0.92 & 14.64 & 15.47 & & & & \\
\hline \multirow[t]{5}{*}{1987} & Budakalaszi-2 & 1.08 & 29.60 & 12.00 & 1.30 & 37.80 & 3.94 & 0.40 \\
\hline & Degumille & 1.04 & 30.70 & 17.80 & 34.60 & 5.90 & 2.90 & + \\
\hline & Csömöri & 0.87 & 23.80 & 15.40 & 54.80 & - & 0.20 & + \\
\hline & Bona & 1.01 & 19.90 & 17.90 & 50.10 & 0.50 & - & + \\
\hline & $\mathrm{X}$ & 1.00 & 26.00 & 15.77 & & & & \\
\hline \multirow{5}{*}{$\begin{array}{l}1988 \\
\text { (a) }\end{array}$} & Budakalaszi-2 & 1.06 & 37.30 & 17.60 & 1.25 & 33.40 & 5.10 & 1.85 \\
\hline & Degumille & 1.16 & 27.60 & 20.00 & 37.40 & 2.45 & 2.45 & + \\
\hline & Csömöri & 1.03 & 43.75 & 10.75 & 38.60 & 0.75 & 0.45 & + \\
\hline & Bona & 1.09 & 33.55 & 16.90 & 44.35 & 0.39 & 0.65 & + \\
\hline & $\mathrm{x}$ & 1.08 & 35.67 & 16.31 & & & & \\
\hline \multirow{6}{*}{$\begin{array}{l}1988 \\
\text { (b) }\end{array}$} & Budakalaszi-2 & 1.07 & 40.65 & 16.95 & 1.55 & 35.30 & 2.35 & 0.95 \\
\hline & Degumille & 1.16 & 34.75 & 20.15 & 37.90 & 2.20 & 2.05 & + \\
\hline & Csömöri & 1.00 & 42.75 & 18.25 & 32.40 & 1.65 & 0.15 & + \\
\hline & Bona & 0.84 & 37.75 & 21.75 & 33.35 & 0.65 & 0.10 & + \\
\hline & $\mathrm{X}$ & 1.02 & 38.97 & 19.27 & & & & \\
\hline & $\mathrm{p}<$ & $\begin{array}{l}0.1 \% \\
5 \%(1987)\end{array}$ & $\begin{array}{l}0.1 \% \\
5 \%(1986)\end{array}$ & $0.1 \%$ & $0.1 \%$ & $0.1 \%$ & $0.1 \%$ & n.c. \\
\hline
\end{tabular}

In Hungary the $\beta$-farnesene content was higher when the summer was warm.

The four-year experiment on the cultivation of chamomile in Finland carried out under very different weather conditions confirmed the results reported earlier by SváB et al. (1967), Honcariv et al. (1979) and Franz et al. (1986). The production of phytomass and the flower yield are influenced by climatic factors rather than by the genetically determined chemical characters of the different varieties or chemotypes.

FRANZ et al. (1986) stated that the oil formation is related to the flower formation.
Since the summer conditions in Finland are suitable for the flower formation of chamomile, there were no substantial changes in the content and composition of the essential oil during the four years of cultivation. The flower yield depends on the field conditions and suitable cultivation techniques. Growers must use the appropriate growing technique for chamomile, especially in the spring period, elaboration of such methods requires more detailed research.

Acknowledgement. The authors wish to thank Y. Holm (Ph.D.) for valuable advice during the preparation of this paper. 


\section{References}

Franz, Ch., Hölz, J. \& Vomel, A. 1978. Preliminary morphological and chemical characterization of some populations and varieties of Matricaria chamomilla L. Acta Hort. 73: 109-114.

Franz, Ch., Moller, E., Pelzmann, H., Härdh, K., Hălvã, S. \& Ceylan, A. 1986. Influence of ecological factors on yield and essential oil of chamomile (Chamomilla recutita (L.) Rauschert syn. Matricaria chamomilla L.). Acta Hort.188, Medicinal and Aromatics V. 157-162.

Galambosi, B., Marczal, G., Litkey, K., Svab, J. \& Petrı, G. 1988. Comparative examination of chamomile varieties grown in Finland and Hungary. Herba Hung. 27: 45-55.

Galambosi, B. 1989. Phytomass production of Medicinal Plants in Finland. Acta Agron. Hung. 38: 89-97.

Gasic, O., Lukic, V., Adamovic, R. \& Durkovic, R. 1989. Variability of content and composition of essential oil in various chamomile cultivars (Matricaria chamomilla L.) Herba Hung. 28: 21-28.

Honcariv, R. \& Repcak, M. 1979. Chemotypes of Matricaria chamomilla L. Herba Polonica. XXV: 261-267.

Holzl, J. \& Dемuth, G. 1975. Einfluss ökologischer Faktoren auf die Bildung des ätherischen Öls der Flavone verschiedenen Kamillenherkunfte. Kritischer Vergleich der quantitativen Bestimmungsmethoden. Planta Medica 27: 37-45.

\section{SELOSTUS}

\section{Neljän kamomillalajikkeen kukkasato ja haihtuvien öljyjen pitoisuudet Suomessa v. $1985-1988$}

\section{B. Galambosi ${ }^{1}$, Zs. Szebeni-Galambosi ${ }^{1}$, M. Repcak ${ }^{2}$ \& P. Cernaj ${ }^{2}$}

\footnotetext{
' Maatalouden tutkimuskeskus, Etelä-Savon tutkimusasema Karila, SF-50600 Mikkeli, Finland.

${ }^{2}$ P.J. Safarik -yliopiston Erikoisbiologinen laitos, Manesova 23, CS-04167 Kosice, Czechoslovakia
}

Vaikka kamomilla (Matricaria recutita L.) kasvaa Suomessa luonnonvaraisena rohdoskasvina käyttävät läăketeollisuus ja luontaistuotekaupat ulkomailta tuotua kamomillaa. Hälvän (1985) selvityksen mukaan maahamme tuotiin esim. v. 19828700 kg kamomillan kukkaa, jonka arvo oli 521000 mk. Laăketeollisuus vaatii kamomillalle tiettyă kemiallista koostumusta, joten eri
HĀLṼ̄, S. 1985. Consumption and production of herbs in Finland. J. of Agric. Sci. in Finland. 57: 231 -237 .

Repcak, M., Halasova, J., Honcariv, R. \& Podhradsky, D. 1980. The content and composition of essential oil in the course of anthodium development in wild chamomile (Matricaria chamomilla L.). Biol. Plant. (Praha) 22(3): 183-191.

SCHANTZ, M. \& SALONEN, R. 1966. Untersuchungen über den Ölgehalt und die Gesamtazuleenmenge wăhrend der Entwicklung der Blutenkörbchen von in Finnland wildwachsender Kamille (Matricaria chamomilla L.). Sci. Phar. 34: 177-185.

Sváb, J., C. El-Din Awaad \& Fahmy, T. 1967. The influence of highly different ecological effects on the volatile oil content and composition in the chamomile. Herba Hung. 6: 177-199.

SváB, J. 1978. Kamilla (Matricaria chamomilla L.) in: ed. Hornok, L.: Gyógynövények termesztése és feldolgozása. p. 248-254. Budapest.

SváB, J. 1981. Biometrical methods in research work. Budapest.

ZALECKI, R. 1978. Organizacja uprawy rumianku pospolitego na surowiec. Wiadomosci Zielarskie. 7: 2-2.

Ms received June 14, 1990 kemotyyppien tutkimus on vălttămătöntă pohjoisissa ilmasto-olosuhteissa.

Kamomillan viljelytutkimus kuului Helsingin yliopiston v. 1984 aloittamaan Puumalan mausteprojektiin. Siină tutkittiin Suomen olosuhteisiin sopivia viljelymenetelmiå ja niiden koneellistamista sekä eri lajikkeiden viihtyvyyttä.

Pirttimäen koetilalla tutkittiin v. 1985-1988 neljän 
lajikkeen satoisuutta ja viihtyvyyttä. Lajikkeet olivat unkarilainen tetraploidi Budakalaszi-2 sekă diploidit lănsisaksalainen Degumille, unkarilainen Csömöri ja tsekkoslovakialainen Bona. Kamomillan siemeniä kylvettiin kevăällä $5 \mathrm{~kg} / \mathrm{ha}$ hajakylvönä maan pinnalle muokattuun maahan $10 \mathrm{~m}^{2}$ :n koeruutuihin. Kokeessa oli kaksi kerrannetta, maalajina hiekkamoreeni ja maan pH -arvo 5,8. Koealueelle levitettiin typpeä $50 \mathrm{~kg} / \mathrm{ha}$, fosforia $80 \mathrm{~kg} / \mathrm{ha}$ ja kaliumia 85 kg/ha. Kukkasato korjattiin käsipuimurilla riipien ja lajiteltiin $18 \mathrm{~mm}$ :n seulalla. Kaikki kukat eivăt irtoa puinnin ja lajittelun aikana. Osa sadosta muodostuu varsista, joissa kukat ovat yhä jäljellä. Tämä ns. kamomillan heinäsato on sopivaa kemialliseen jatkojalostukseen uuttamis- ja tislaamismenetelmien avulla.

Viljelyvuosien saaăolosuhteet vaihtelivat paljon. Vuosina 1986 ja 1988 kasvukausi oli $2-4^{\circ} \mathrm{C}$ keskimäăräistă lămpimămpi ja sademaaără vastaavasti keskimääräistă pienempi. Vuonna 1987 kasvukausi oli $3^{\circ} \mathrm{C}$ keskimäăräistă kylmempi ja myős sateinen. Kasvukauden säă vaikutti merkittăvăsti kamomillan kukka- ja heinäsatoon. Vuon- na 1985 saatiin korjattua kaksi satoa, mutta kahtena seuraavana vuonna vain yksi onnistunut sato. Paras tulos saavutettiin v. 1988, jolloin satoa korjattiin kolme kertaa.

Lajikkeiden tuore kukkasato oli neljăn vuoden keskiarvona $0.4 \mathrm{~kg} / \mathrm{m}^{2}$ ja tuore heinäsato $0.2 \mathrm{~kg} / \mathrm{m}^{2}$. Tămă vastaa keskieurooppalaista kevătkylvőstä saatua satoa, jota saadaan yleensă văhemmăn kuin syyskylvőstă.

Kuivattujen kukkien kemiallinen analyysi osoittaa, että tetraploidi lajike on bisabololoksidi-A -tyyppiä ja diploidit lajikkeet ovat alfa-bisabololi -tyyppiä. Lajikkeiden haihtuvan öljyn pitoisuuksissa ja koostumuksessa ei tapahtunut merkittäviă muutoksia, vaikka viljelyvuosien săăolosuhteet vaihtelivatkin paljon.

Tämă viljelytutkimus antoi năytön siită, että etelăisessä Suomessa on mahdollista saada hyvălaatuinen kamomillan kukkasato. Tulevaisuudessa onkin tarpeellista tutkia myös kamomillan syyskylvőa ja sen vaikutusta sadon măăräăn. 